\title{
Translation Bias: Impact of Gender in the English Translation of the Bible
}

\author{
Adejoke O. Olughuyi and Virginia C. Okafor
}

\begin{abstract}
Some critics of the Bible believe that the translation of the Bible does not give prominence to the role of women. Thus, such critics claimed that the translation of the Bible is biased. This paper considers the aspect of the Bible where issues relating to women are discussed. Some versions of the English translation were compared to see if there are divergent views in the different versions of the English translation. It is observed that the two versions expressed the same view about women even though the words used in translation were not identical. Therefore, it is concluded that the translation is not biased since it is not the view of a single translator. Furthermore, the translation is in agreement with the culture, religious law, and general belief of people as well as the original writer of the Bible.
\end{abstract}

Index Terms-Bible, gender, impact, translation.

\section{INTRODUCTION}

Before the construction of the Tower in Genesis 11:1-9 "the whole earth was of one language and of one speech". It was at Babel that God confounded the people's language and scattered them abroad. Since then there has been multiplicity of languages and communities. As a result of divergence of languages there is need for translation to foster interaction amongst the different nations of the world. For religious interaction and harmony the bible which was originally written in Hebrew language has to be translated into different languages.

Therefore, this paper wants to consider the English translation of the bible. There are many versions of the English translation. For the discussion in this paper King James Version and Easy-to-Read Version of World Bible Translation Center shall be cited. Based on these English versions of the Bible some of the points raised against the translated version of the Bible will be considered.

\section{StATEMENT OF THE Problem}

Some critics of the Bible translation claimed that the translation of the Bible is gender biased. It was observed that:

1) The impact of the female in the bible is not properly highlighted

2) When referring to God the Father, the Son and the Holy Ghost the pronoun he and not she are used for the Holy Spirit. If the Holy Spirit can fill both male and female why can we not use she to refer to the Holy Spirit as

Manuscript received September 12, 2015; revised November 24, 2015.

The authors are with the Federal Polytechnic, Ado Ekiti, Nigeria (e-mail: adejokeolugbuyi@yahoo.com). well as highlighted.

\section{JUSTIFICATION OF THE CLAIM}

In the record of geology in Genesis 4:17-26, only the names of male children are mentioned, women and children are considered anonymous. In the New Testament where it was recorded that Jesus fed above four hundred people, only men were counted, women and children were excluded. We can see this in the book of Matthew 15: 38 "and they that did eat were four thousand men, beside women and children.' (King James). Gospel of Luke 9:14 says "and they were about five thousand men there". (World Bible Translation). Thus women were not recognized.

Furthermore, in 1Thimothy 2:11-14 Paul says: "Let the woman learn in silence with all subjection. But I suffer not a woman to teach, nor to usurp authority over the man but to be in silence. For Adam was first formed, then Eve. And Adam was not deceived, but the woman being deceived was in the transgression."(King James) [1]

"A woman should learn while listening quietly and while being fully ready to obey. I don't allow a woman to teach a man. And I don't allow a woman to have authority (power) over a man. The woman must continue in quietness. Why? Because Adam was made first. Eve was made later. Also, Adam was not the one the devil tricked. It was the woman who was tricked and became a sinner." (World Bible Translation) [2].

From the above quotations it is evident that women were not permitted to teach or speak publicly in the church or any religious gathering. However, the reason for the above injunction by Paul as recorded in this book of 1 Timothy is given in 1 Corinthians 14:34-35 and 1 Corinthians 11:3:

"But I would have you know that the head of every man is Christ: and the head of the woman is the man..."

Thus the man is the head of the woman, therefore, she should learn through the man. Thus 1 Corinthians 14:34-35 says:

"Let your women keep silence in the churches: for it is not permitted unto them to speak: but they are commanded to be under obedience, as also saith the law.

And if they will learn anything, let them ask their husbands at home: for it a shame for women to speak in the church."

From this quotation, it shows that the law forbids women to speak in public. The translator of any text must have understanding as well as adequate knowledge of both the language and the culture of the users of the Source Language and the Target Language. He is not only transferring the source language to his target audience, he is equally transmitting the ideas, beliefs and even the culture 
of the users of the source language as well. At the same time, the translator must present his text in acceptable and accurate form to the target audience. This was confirmed by Kolawole [3] when he said that:

"A literary translator needs to be able to assess not only the literary quality of the text but also its acceptability to the target reader. The literary translator should have a deep knowledge of cultural and literary history of both the source and the target languages."

Therefore, from the above assertion, the translator is only in line with the law, religion and the culture of the people for whom the text is translated. The religious law must be observed in translation if the text is to be acceptable to the people using the Bible. In most countries and churches where the Bible is used today, the belief that women should be submissive to men is upheld.

Another aspect of the question raised by the critics is the use of him and not her for the Holy Spirit. This is in line with the religious belief that God the Father, God the Son and God the Holy Spirit are one in Trinity. Therefore, the Holy Spirit should be a man and not a woman. The only place where God is compared to a woman in the Bible is in Isaiah 49:14-15:

"But Zion said, The Lord has forsaken me, and my Lord hath forgotten me. Can a woman forget her suckling child, that she should not have compassion on the son of her womb? Yea, they may forget, yet will I not forget thee."

In the translation of the Bible, the use of he for living being is more than the use of she. Example of such is found in Epistle of John 14:26 and John 16:13-14:

"But the Comforter which is the Holy Ghost, whom the Father will send in my name, he shall teach you all things, and bring all things to your remembrance..." (King James)

"But when the Spirit of truth comes, he will lead you into all truth. The Spirit of truth will not speak his own words. He will speak only what he hears. He will tell you the things that will happen. .... He will get things from me and tell them to you." (World Bible Translation)

Also, John 1:1-4 says

"All things were made by him and without him was not anything made that was made. In him was life and the life was the light of men."

If the law, religion and culture of the people uphold the belief that men should be the head of women, then it means that men are superior to women by this belief. God is above all and He is superior to man, therefore, wisdom demands that he and not she should be used for God.

It is evident from the above quotations that we have more than one English version of Bible translation. It is also true that all the versions reflect the belief that women should not speak publicly in the church. All the versions use he for the Holy Spirit. In all the versions, only men are counted in the feeding of the five thousand or four thousand people. They do not all agree on the actual number of people that were fed. However, they all agree that only men were counted. Women and children were not counted and they remain anonymous.

Another truth that is established from the above quotations is the fact that the different versions of the English translations do not contain exactly the same set of words and the same sentence pattern even though the translations conveyed the same message or the same idea or belief. Therefore, the question that is now raised is, how do we translate? How can we ensure good translation? There is need to know what a good translation is and there is need to consider it in relation to the points stated above.

\section{WHAT IS TRANSLATION?}

There are so many definitions of the term translation. The Oxford Companion to the English Language [4] says that 'translation is the communication of the meaning of a source-language text by means of an equivalent target language text'. B. J, Chutte cited by Ojeaga Paul [5] says that:

"Translation is a bridge between cultures... Without translation our world would narrow mercilessly. Like air and sunshine and good growing earth in the natural world, translation is our necessity in the creative world."

According to Cohen [6] whereas interpreting antedates writing, translation began only after the appearance of written literature. Furthermore, translators always risk inappropriate spill-over of source-language idiom and usage into the target - language translation. When target language lacks terms that are contained in a source language, translators would borrow those terms (from the sourcelanguage), thereby enriching the target language. This is made possible through the exchange of calques and loan words between languages and their importation from other languages.

Translation is an art and as such, it is not an easy task. Thus, Kasparek [7] says that if translation is to be true, the translator must know both languages" (the source-language and the target-language).

It is observed that no dictionary or thesaurus can ever be fully adequate guide in translating. Thus, Alexander Tyler [8] in his book "Essay on the Principles of Translation" (1790) emphasized that "assiduous reading is a more comprehensive guide to a language than are dictionaries". Also, Ignacy Krasicki [9] says that "translation ... is in fact an art both estimable and very difficult and therefore is not the labour of common minds."

Translation can either be good or bad. For it to be considered good it must be an accurate equivalent of the source text. It must be a 'perfect transfer' of the original text. It must present authentic style and intention of the author. Lefevre (1992), cited by Kolawole [10] describes translation as "rewriting of an original text". A good translation must be able to reconstruct the author's intent in another linguistic medium. He should be able to reproduce the effects as well as the contents of the original text. A good and faithful translator is one who is able to write in a style that is not his own and he is able to make it good by preserving the tonal and associative reverberating qualities of the original text.

It is also important to note that translation cannot be studied in isolation from the society, history and culture. Language is not the only factor that influences translation. Kolawole (2011) confirms this that transmission of ideology between different nations and countries among other factors can also influence translation. Ideology determines translator's style and choice of words and consequently affects the receiver's world view. 
What is ideology in translation? It is the evaluative beliefs - traditionally referred to as 'attitudes shared by social groups' Kolawole (2011). Thus, what is translated would be influenced by the translator's political, religious, social or cultural beliefs or ideology. Translation depends on whether the translator agrees or disagrees with the dominant ideology of his time. In fact, every written text is for a purpose and it is meant for certain set of people. It is very essential for translators to know why a text is written and why it needs to be translated.

Translation is not just a movement between two languages but also between cultures. It involves replacing items whose roots are in the Source Language culture with elements that are indigenous to the Target Language. The translator exercises certain level of choice in his or her use of indigenous features. Thus, success in translation sometimes, depends on the translator's command of cultural assumptions in each language in which he or she is working. Ease in translation depends on the extent of shared assumptions between the source and target culture. Even where cultures are similar they have areas where overlap is partial.

In translation, there is no perfect equivalence between languages. The fact that there are different versions of the English translation of the Bible indicates that there is no perfect and complete equivalence in translation. Consider the translation of Jeremiah 29:11 for instance, what is translated as expected end in King James Version is translated as a future and a hope in the World Bible Translation. The lack of perfect and complete synonyms makes room for compensation or substitutes. This can further be explained when we consider the issue of synonyms. Words have different meanings according to different contexts in which they are found. The Dictionary gives meanings of words - that is denotative meanings or the core meanings of words. For example, salt can be said to mean sodium chloride while man can mean adult male human being. The two words man and salt are expressing scientific facts. To understand the meaning of both, you only need empirical evidence.

The expression man which according to the dictionary definition (denotative meaning) is interpreted as adult male human being can take up a different meaning in expression he is not a man or are you not a man?. Also, the word salt, in expression his tongue is very salty does not give the meaning of sweetness as in sodium chloride. Rather, it connotes the idea of bitterness in the use of his tongue.

Furthermore, words such domicile, residence, abode, as home, and house may be defined as denoting the building in which we live. Nevertheless, they are by no means interchangeable because their connotations are different. For all of them, their denotative meaning can be physical building but they all have different connotation from one another. Thus, a word can have both kinds of meaning. For example the word murder has the denotative meaning of termination of life (kill) and connotative meaning of doing so for no just cause. There are two relevant ways of distinguishing meanings in words. The first relates to giving scientific description or report while the second involves expressing opinions or attitudes. Connotative meanings are culture bound.
In view of the above explanation, the use of man in the Bible passage cited can be said to include women since it is culturally believed that the use of the word man connotes mankind. Man is representative of all mankind. Language reflects culture. Translation is more than substituting one language for the other; rather, it is also a replacement of one culture with another culture. This cultural transposition is contained in all translation. The success of translation is the ability of the translator to understand the appropriate use of cultural traits in each of the two languages of his work - the Source Language and the Target Language.

Communicative translation may be employed instead of literal translation. According to Lederer [11] word for word translation can give linguistic or structural equivalence but not the actual meaning of the original expression. For example, to translate the expression I am hungry in French, you will not say Je suis faim but J'ai faim. Other examples are: $\mathrm{j}$ 'ai froid I am cold; Il fait chaud it is hot etc. To translate idiomatic expressions and proverbs one cannot go by literal translation to get the real meaning of expressions. If one does so such translation will be nonsensical. For example the expression - practice makes perfect- is translated in French as c'est en forgeant qu'on forgeron; a stitch in time saves nine is translated as un point a temps en vaut dix; a word is enough for the wise is translated as $a$ bon. entendeur, salut

The translator must try his best to make his message clear, legible and comprehensive to his intended audience or reader. He should go beyond word for word translation to the level of comparing the two languages in order to get the right equivalence or the right meaning of his message.

According to Seleskovitch and Lederer [12] translators and interpreters have the same objective - "communicating the thought of others "Above all, a translator does the work of an interpreter. Speech exists before writing thus; the translator's task is to convey the mind of the writer to the readers. He should not translate a word or an expression out of context. Rather he should translate the original intention of the writer to the reader. The main objective of the translator is to convey the original message of the text. He is to read and decode the message of the text so as to convey the real meaning to the readers. The translator must understand the language as well as the extra linguistic features in the message of the author as well as the world view of the audience so as to convey the exact message of the writer to the target audience.

The approach of Lederer and that of Freud is similar. Freud [13] cited by Bariki (1999:82) says: The translator "au lieu de lui transposer laborieusement les formules de la langue etrangere et de s'attarder sur chacune de ses expressions, il lisait un passage, refermait le livre et redigeait son texte." (The translator "instead of transposing laboriously the formular of the foreign language and focusing on every expression, he would read the passage close the book and rewrite the message.) That means that the translator has to reformulate the message by expressing the ideas of the writer without using the same words used by the writer.

Elizabeth Lavault [14] and Mariane Lederer [15] identified three levels of translation:

1) The level of usage out of context 
2) The level of usage in verbal context

3) The level of usage within the frame of experience or knowledge of the translator. (le baggage cognitive du traducteur).

These can be explained with the expression "You want it"" as follows:

First level - out of context 'You" can be interpreted as "you" singular or plural

"want" can be interpreted as 'desire', 'need' or 'want'.

Second level - when each word is put in a verbal context - eg 'I want some money'

According to Lederer it is the frame of knowledge or the experience of the translator that will help him to understand the message properly to be able to convey the mind of the writer to the readers. The frame of knowledge is what gives translator the competence to be able to convey the real intention of the writer to the readers. What constitutes the frame of knowledge of the translator is his memory, total experience, linguistic and extra- linguistic knowledge, his world view and so on. The translator also needs a good dictionary to be able to do his work properly.

Finally, it should be noted that every language has its own linguistic and structural peculiarities and is characterized by its special traits or qualities in the formation of words and sentences. That is why Sapir cited by Ojeaga (2000:345) says that

"No two languages are ever sufficiently similar to be considered as representing the same social reality. The world in which different societies live, are distinct worlds, not merely like the same world with different labels attached."

Each language is distinct from others by its divergence of cultural, political, economic and social life of the people using the language. The translator therefore, must have good knowledge of the target language, its structure and the culture of its users so as to be able to employ words and sentences that are equivalence of the source language.

\section{CONCLUSION}

From the translation of the two versions of the Bible, it is evident that the translators did not use exactly the same set of words but the ideas and messages conveyed are the same on the issue of female folk or women. This shows that the translation is not biased. Rather, the translation is a reflection of the religious and sociological belief that man is superior to woman for two reasons: First, as the first creature of God and second, as the head of the family. There is confirmation of this from the Bible in Genesis Chapter 2: 15, 21-22 and Ephesians 5:22-23. Furthermore, the use of man presupposes women and children since man connotes mankind.

From the discussion above, translation is more than replacing one language with another. If translation is to be acceptable to the reader, the translator, while conveying the message of the writer, must take cognizance of the cultural, religious and sociological beliefs of the target audience. What the English Translators of the Bible presented is in line with the religious beliefs of the users of the Bible. It is the real message of the original writer.

The Bible has been translated into so many languages and different versions, but as Lederer has said, there is possibility for individuals to interpret the Bible out of context. One can decide to substitute she for he in referring to the Holy Spirit. Individuals can decide to interpret the Bible to suit his or her own belief but the duty of the translator is to portray or reflect the mind of the original writer to the public.

\section{REFERENCES}

[1] K. James and H. Bible, Authorized Version, Bible Society of Nigeria, Lagos, 2013.

[2] World Bible, Holy Bible World Translation Center, Fork Worth, Texas. 2000

[3] S. O. Kolawole, "Ideology in literary translation: The case of the English version camara laye's le regard DU roi as radiance of the King," Cross-Currents in Language, Literature and Translation, Edition: Sonou d'AFRIQUE-Universite Bilingue, Porto-Novo, Republique du Benin.

[4] The Oxford Companion to the English Language, Namit Bhatia, ed., 1992, pp. 1051-1054.

[5] O. Paul, "The possibilities of good translation," Nigerian University French Teachers Association (NUFTA), Uturu, 8th-11th November, 2000, p. 354, pour Traduire.

[6] J. M. Cohen, "Translation," Encyclopedia Americana, 1986, vol. 27, pp.12.

[7] C. Kasparek, "The translator's endless toil," The Polish Review, vol. XXVIII, no. 2, 1983, pp. 84-88.

[8] A. Tyler, Essay on the Principles of Translation, John Benjamin's Publishing Company, Edinburg.

[9] I. Krasicki, "Oliumac zemu Ksiag” On Translating Books, 1803.

[10] Kolawole S.O. Op Cit, 2011.

[11] M. Lederer, Translation Today, the Interpretative Model, Lille, 1994.

[12] D. Seleskovitch and M. Lederer, Interpret to Translate, Paris: Didier, Erudition, 1986, p. 10

[13] I. Bariki, Appliied Translation and French in Nigerian Universities, Thesis for doctorate degree University of Ilorin, Ilorin, 1999.

[14] E. Lavault, Function of Translation in Didactic Languages Paris: Didier Erudition, 1985.

[15] M. Lederer, C. B. Mulgrew, and P. M. Grant, "A clustering technique for digital communications channel equalization using radial basis function networks," IEEE Trans. on Neural Networks, vol. 4, pp. 570578, July 1993.

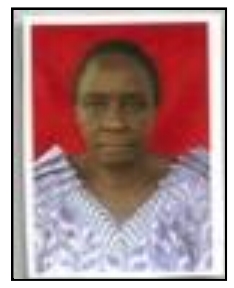

Adejoke O. Olugbuyi was born in Ikole Ekiti, Ekiti State Nigeria in 1951. She had her primary and General Certificate in Education in Oy State. She obtained her bachelor of arts degree in French language at the University of Ife (now Obafemi Awolowo University) in 1975. She has master's degree in communication arts (MCA) at the University of Ibadan in 1988 and in 2011 another master's degree in French language at the University of Ilorin, Nigeria.

She is a chief lecturer in federal polytechnic, ado ekiti and she has been teaching French language and communication in English, Technical Report Writing since 1978 to date. She has published many books and several articles both in local and international Journals. Some of her published works include: "Communication in English Made Simple" R. R. R. Educational publisher, Akure 2002. "Use of English and Communication Skills, Corporte Max, Ilorin. 2007. Her Journal articles include: "Language and Translation as weapons of Effective Communication and Success in Ministry" in Literacy Information and Computer Education Journal (LICEJ) Vol. 5, Issue1 2014.

Mrs Olugbuyi is a member of Modern Language Association of Nigeria, (MLAN); Nigeria Association of French Teachers (NAFT); Nigeria English Studies Association (NESA); and Institute of Strategic Management, Nigeria (ISMN). 